70 kyr. Kanfoush et al. (2000) noted that IRD pulses in the S. Atlantic Ocean coincided with warm periods when production of North Atlantic Deep Water (NADW) was enhanced in the northern hemisphere and sea level rose; both processes leading to destabilization of Antarctic ice shelves and the promotion of icebergs.

This brief synthesis of Southern Ocean research highlights the interactions of the atmosphere, ocean and cryosphere of the two hemispheres as they vie for control of the climate machine. It is an exciting challenge to clarify these inter-relationships in order to understand how the planet "ticks" and so to better gauge its responses to a rapidly changing climate.

\section{Note}

The majority of data presented in this article comes from existing datasets available in the World Ocean Circulation Experiment Southern Ocean Atlas (http://wocesoatlas.tamu.edu/)

\section{References}

Barrows, T.T., Juggins, S., de Deckker, P., Calvo, E. and Pelejero, C., 2007: Long-term sea surface temperature and climate change in the Australian-New Zealand region, Paleoceanography, 22: PA2215, doi.10.1029/2006PA001328.

Carter, L., Manighetti, B., Ganssen, G. and Northcote, L., 2008: SW Pacific modulation of abrupt climate change during the Antarctic Cold
Reversal -Younger Dryas, Palaeogeography, Palaeoclimatology, Palaeoecology, 260: 284-298.

Cortese, G., Abelmann, A. and Gersonde, R., 2007: The last five glacialinterglacial transitions: a high-resolution 450,000 year record from the subantarctic Atlantic, Paleoceanography, 22: PA4203, doi:10.1029/2007PA001457.

Gersonde, R., Crosta, X., Abelmann, A. and Armand, L., 2005: Sea surface temperature and sea ice distribution of the Southern 0 cean at the EPILOG Last Glacial Maximum - a circum-Antarctic view based on siliceous microfossil records, Quaternary Science Reviews, 24 869-896.

Howard, W.R. and Prell, W.L., 1992: Late Quaternary surface circulation of the Southern Indian 0cean and its relationship to orbital variations, Paleoceanography, 7: 79-117.

For full references please consult:

www.pages-igbp.org/products/newsletters/ref2009_1.html

\title{
New records of the role of Antarctic ice sheets in late Cenozoic climate
}

\section{Ross Powell ${ }^{1}$, T. Naish ${ }^{2}$, R. LeVY ${ }^{3}$ And the MIS SCIENCE TEAm ${ }^{3}$}

'Department of Geology and Environmental Geosciences, Northern Illinois University, DeKalb, USA; ross@geol.niu.edu

${ }^{2}$ Antarctic Research Centre, Victoria University of Wellington, New Zealand, and Geological and Nuclear Sciences, Lower Hutt, New Zealand; ${ }^{3}$ ANDRILL Science Management Office, University of Nebraska at Lincoln, USA

\section{New drill core records of Plio-Pleistocene age from Antarctica include evidence of significant changes in ice sheet regime younger than $14 \mathrm{Myr}$ and an obliquity-driven dynamic marine-based ice sheet prior to 800 kyr.}

Although Antarctica's ice sheets contain the world's largest terrestrial water reservoir, their influence on Late Cenozoic (14 Myr ago) sea level and climate remains poorly known from proximal records. Consequently, the role of Antarctica's ice sheets in global sea level and climate relies heavily upon inferences from oxygen isotope records from deep-sea cores. Although these isotopic records have revolutionized our understanding of climate-ice-ocean interactions, questions remain about the specific contribution of Antarctica's ice sheets.

Various lines of evidence, including geomorphic studies from the Transantarctic Mountains (TAM), suggest that the East Antarctic Ice Sheet (EAIS) has been quite stable for the past $14 \mathrm{Myr}$ (Sugden et al., 1993). However, oxygen isotope records indicate moderate oscillations of global ice volume capable of producing sea level fluctuations of $<25 \mathrm{~m}$ above present, prior to the development of northern hemisphere ice sheets about 3 Myr ago. These ice volume changes must have involved a Greenland ice cap, the West Antarctic Ice Sheet (WAIS), and margins of EAIS. A more dynamic view of the late Cenozoic EAIS has been proposed from a number of on-land geological studies, with evidence (from marine diatoms in glacial sediments) of marine incursions into the continental East Antarctica during the Pliocene (5.3-1.8 Myr ago) requiring a significant deglaciation of the interior of EAIS (Webb et al., 1984; Har- wood et al., 2000). However, the origin of the diatoms has been called into question (e.g., McKay et al., 2008), and uncertainty remains over the scale of Antarctic ice sheet dynamism. While this debate continues, the Early and middle Pliocene (5-3 Myr ago) is generally regarded as a time of global warmth and is, therefore, an important window into Earth's future climate in the context of anthropogenic warming.

During the austral summer of 20062007, a new Antarctic geological drilling program (ANDRILL) recovered a 1285-mlong record of climate and ice sheet variability spanning the past $14 \mathrm{Myr}$. This AND$1 \mathrm{~B}$ core came from beneath the 85 -m-thick McMurdo Ice Shelf (MIS), within an 850-mdeep sedimentary basin surrounding Ross Island (Fig. 1). The core provides the best direct evidence of past Antarctic Ice Sheet (AIS) and climate fluctuations for this time interval, enabling comparison with deepsea isotope records, low-latitude continental margin sea level records, and numerical climate and ice sheet models, especially for times of past global warmth. A synopsis of the initial results from AND-1B (Naish et al., $2007 ; 2008$ ) is presented here, focusing on their potential to improve our knowledge of Antarctica's influence on, and response to, global climate change.

\section{Glacial-Interglacial cycles from the MIS Project}

Strata of AND-1B core accumulated in deep water (200-1000 m), $100 \mathrm{~km}$ from the
Victoria Land coastline, western Ross Sea. The diverse range of rock types represent particular past environments that included open marine diatomites (rock made from siliceous diatom remains), mudstones and turbidites (deposits formed by instantaneous downslope movement of sediment) deposited during interglacials from local sources, ice-proximal massive and stratified diamictites (poorly sorted conglomerate), and conglomerates and sandstones representing glacial periods. During glacial periods, the ice sheet had an extensive marine terminus perhaps hundreds of km north of the drill site in the Ross Sea. During interglacials, the drill site was either covered by an ice shelf (similar to present day) or lay in open or sea-ice-covered seas, while the ice sheet had retreated onto the continent with deposition of marine diatoms or terrigenous mud from local streams, and occasional debris from icebergs.

A preliminary age model for the upper $700 \mathrm{~m}$ of drill core constructed from diatom biostratigraphy and radiometric ages on volcanic material allows a unique correlation between about $40 \%$ of the magnetic polarity stratigraphy and the geomagnetic polarity timescale. The age model provides several well-constrained intervals displaying relatively rapid $(<1 \mathrm{~m} / \mathrm{kyr}$ ) and continuous accumulation of sediment, punctuated by several 0.5-1 Myr stratal hiatuses representing more than half of the past $7 \mathrm{Myr}$. Thus, the AND-1B record provides several highly resolved "windows" into late Ceno- 


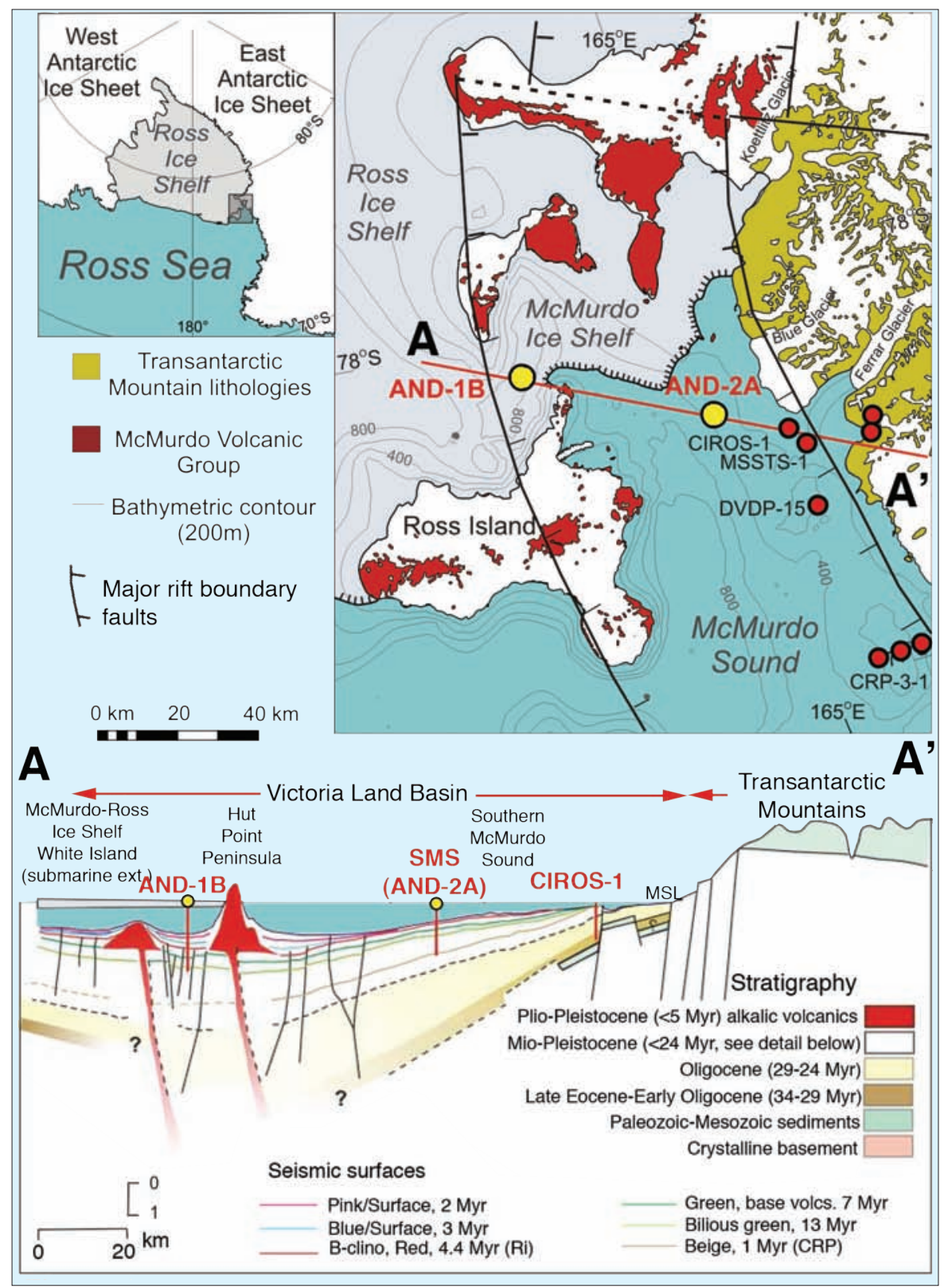

Figure 1: Top diagrams show the location of key geographical, geological and tectonic features in southern McMurdo Sound, with ANDRILL's two new drill sites shown as yellow circles. Boundary faults of the southern extension of Terror Rift are also shown as black hatched lines. Bottom diagram is a schematic structural-stratigraphic cross-section across the Victoria Land Basin $\left(A-A^{\prime}\right)$, and shows the stratigraphic context of the MIS and Southern MCMurdo Sound (SMS) drill sites with respect to previous drill cores (CIROS-1, MSSTS-1, DVDP and CRP) and interpreted seismic reflection data.

zoic development of Antarctic ice sheets. Strata below $\sim 700 \mathrm{~m}$ core depth are late Miocene in age (5-13 Myr ago).

The $>60$ cycles of grounded ice sheet advance and retreat record the evolution of the AIS since a profound global cooling step in deep-sea oxygen isotope records $\sim 14$ Myr ago. Each cycle begins with a glacial erosion surface created by the sole of the advancing ice sheet on the seabed. Above this, coarse-grained, ice-proximal sediments pass upward into a sequence reflecting retreat of the grounding line, sometimes with rapid transitions into open-ocean environments during interglacial times. These retreat sequences may pass back into ice re-advance deposits before being overridden by the ice sheet, creating another glacial erosion surface. Till composition indicates that the depositing

\section{Late Cenozoic Antarctic climate and global implications} orbitally influenced, glacial-interglacial oscillations of the ice sheets during four different phases of late Cenozoic climate evolution.
The glacimarine sedimentary cycles reflect
1. A colder period of polar ice sheets dominated the early-late Miocene, 13.5-10 Myr ago, consistent with inferred cooling from the oxygen isotope record. These cycles are almost entirely glacial diamictites with minor interglacial glacimarine mudstones.

2. An increase in submarine outwash deposits indicates a significantly warmer period of subpolar ice sheets during latest Miocene, 9-6 Myr ago. Open-water, ice distal conditions occur during interglacials, with ice grounded at the site during glacial maxima implying important changes in ice sheet volume.

3. Cyclic variations in deposition units (facies) and chronostratigraphic constraints link ice sheet extent to orbitalscale climate cycles that appear to be $\sim 40 \mathrm{kyr}$ duration during the Pliocene (5.3-1.8 Myr ago) (Naish et al., 2008). Our data provide the first direct evidence of orbitally controlled oscillations of a marine-based ice sheet (cf., Raymo and Huybers, 2008) in Ross Embayment, which periodically contracted onto terrestrial Antarctica when planetary temperatures were up to $\sim 3^{\circ} \mathrm{C}$ warmer than today and atmospheric $\mathrm{pCO}_{2}$ may have been $400 \mathrm{ppm}$. A feature of particular interest is an $\sim 60 \mathrm{~m}$-thick interval of diatomite deposited during part of the warm Pliocene, representing an extended period ( 200 kyr) of locally open water, high phytoplankton productivity and retreat of the glaciers on land.

A significant change in thermal regime of the ice sheet is coincident with a global cooling trend between 3-2.5 Myr ago, evident in global oxygen isotope records, associated with onset of northern hemisphere glaciations. During this time, the WAIS and the coastal margins of the EAIS cooled towards their present polar state, expanding and developing more permanent marine termini and ice shelves. Further expansion of the WAIS occurred across the Mid-Pleistocene Climate Transition ( 900-600 kyr ago).

4. A return to cold polar glaciation dominated by extensive ice sheets during the past $800 \mathrm{kyr}$ is represented in the upper $83 \mathrm{~m}$ of core (Fig. 2). Thin units of sandstone, mudstone, and volcaniclastic sediment (reworked volcanic deposits) occur in the upper parts of the cycles, and these units may indicate that the ice shelf location was similar to present interglacial conditions, with the calvingline remaining near the drill site.

Preliminary paleoenvironmental reconstructions imply changes in Antarctic ice volume have contributed significantly to sea level and ocean circulation on Milankovitch timescales, and that the AIS has played an active, dynamic role in global changes over the past 13 Myr. 


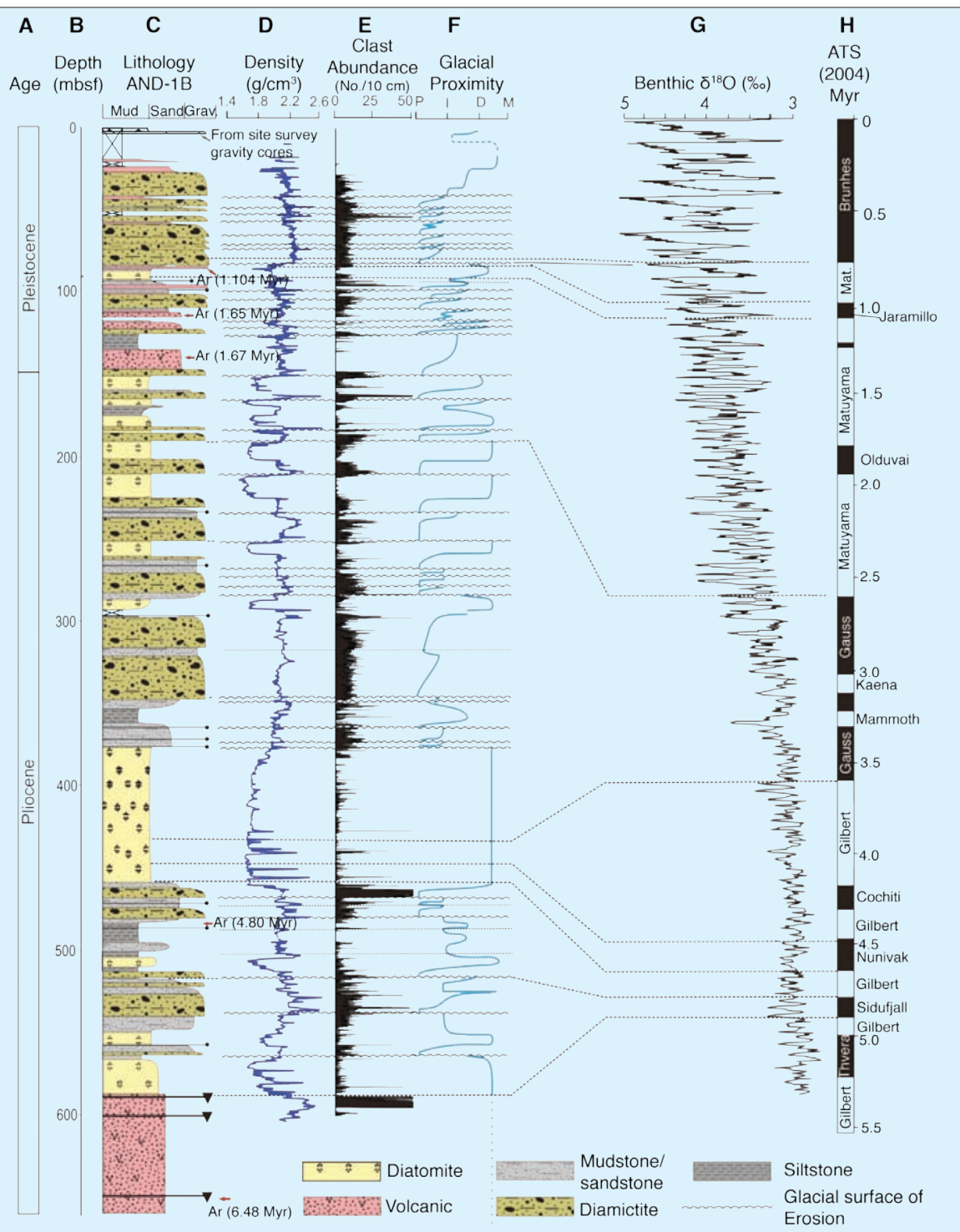

Figure 2: Lithological column of the upper 600 m of the AND-1B drill core recovered by the ANDRILL MCMurdo Ice Shelf Project. Columns from left to right: $\boldsymbol{A}$ ) geological age; $\boldsymbol{B}$ ) depth in $\mathrm{m}$ below sea floor (mbsf); $\mathbf{C}$ ) lithological log with main rock types detailed below and column width scaled to sediment particle size; $\boldsymbol{D}$ ) rock density log $\left(\mathrm{g} / \mathrm{cm}^{3}\right)$; $\left.\boldsymbol{E}\right)$ gravel-size clast abundance (clast number $/ 10 \mathrm{~cm}$ length); $\boldsymbol{F}$ ) glacial proximity curve based on facies where $p=$ proximal, $i=$ intermediate, $d=$ distal, $m=$ open marine; $\boldsymbol{G})$ benthic oxygen isotope $\left(\delta^{18} \mathrm{O}\right.$ in ppt) deepsea record (Lisiecki and Raymo, 2005) for comparison of ice sheet events; $\boldsymbol{H}$ ) paleomagnetic reversal stratigraphy and the 2004 astronomical time scale (ATS) in Myr. Black lines with inverted triangle = thin conglomerate beds; black lines with circles $=$ thin diamictite beds; red arrows $={ }^{40} \mathrm{Ar}{ }^{39} \mathrm{Ar}$ dates on volcanic material: dashed horizontal lines represent paleomagnetic constraints on the correlation of the AND-1B cycles with the deep-marine oxygen isotope curve (see Naish et al., in prep., for detailed correlations).

\section{Note}

Updates on ANDRILL science results, planning documents, background information, and education and outreach resources are available at www.andrill.org. At the time of writing, ANDRILLMIS data remain in moratorium; databases and samples may be requested and accessed after June 2009 through information available on the ANDRILL website.

\section{Acknowledgements}

The ANDRILL project is a multinational collaboration between the Antarctic Programs of Germany, Italy, New Zealand and the USA. The US National Science Foundation, NZ Foundation for Research, Italian Antarctic Research Program, German Science Foundation and AlfredWegener-Institute jointly supported scientific studies; the Science Management Office is at the University of Nebraska, Lincoln. Antarctica New Zealand is the project operator, and has developed the drilling system in collaboration with Alex Pyne at Victoria University of Wellington and Webster Drilling and Enterprises Ltd. New Zealand.

\section{References}

Lisiecki, L.E. and Raymo, M.E. 2005: A Pliocene-Pleistocene stack of 57 globally distributed benthic $\delta^{180} 0$ records, Paleoceanography, 20 PA1003; doi:10.1029/2004PA001071.

Naish, T.R., et al., 2008: Late Cenozoic climate history of the Ross Embayment from the AND-1B drill hole: Culmination of three decades of Antarctic margin drilling. In Cooper, A.K. et al. (Eds), Antarctica: A Keystone in a Changing World. Proceedings of the 10th International Symposium on Antarctic Earth Sciences: 150pp. Washington, DC, The National Academies Press: 71-82.

Raymo, M.E and Huybers, P. 2008. Unlocking the mysteries of the ice ages, Nature, 415: 284-285.

Sugden, D.E., Marchant, D.R. and Denton, G.H. (Eds.), 1993: The case for the stable East Antarctic lce Sheet: The background, Geografiska Annaler Series A, Physical Geography, 75: 151-155.

Webb, P.N. Harwood, D.M. McKelvey, B.C. Mercer, J.H. and Stott, LD, 1984: Cenozoic marine sedimentation and ice-vol ume variation on the East Antarctic craton, Geology, 12: 287-291.

For full references please consult:

www.pages-igbp.org/products/newsletters/ref2009_1.htm

\section{PAGES Arctic2k Metadatabase}

\section{}

Future progress in understanding climate history will depend increasingly on the provision of welldocumented data. Towards this goal, PAGES has developed a number of regional metadatabases (www. pages-igbp.org/science/databases).

The Arctic 2k Metadatabase is a collection of proxy datasets from the Arctic, with focus on the last 2000 years. It provides meta-information on proxy sites of different natural and human archives that might be suitable for climate reconstructions of high temporal resolution. The focus is, therefore, on data with at least decadal resolution. Some of the datasets are freely accessible, others can be provided on request from the corresponding contributor.

For more information, please visit the Arctic2k Working Group website: www.pages-igbp.org/science/arctic $2 k$ / 